\title{
Effect of Soil and Water Salinity on The Quality of Deglet Noor Dates In Biskra Region, Algeria
}

\author{
Haddou Messaouda ${ }^{1,2, a)}$, Babahani Souad ${ }^{1,2, b)}$ and Masmoudi Ali $^{3, c)}$ \\ ${ }^{I}$ Departement of Agronomic Sciences, University of Kasdi Merbah, Ouargla. \\ ${ }^{2}$ Laboratory of Saharan Bioresources: Préservation and valorization, University of Kasdi Merbah, Ouargla. \\ ${ }^{3}$ Departement of Agronomic Sciences, University of Mohemed Khider, Biskra. \\ ${ }^{a)}$ Corresponding Author: haddoumessaouda@gmail.com \\ ${ }^{b)}$ babahani.souad@gmail.com \\ c) masmoudi2001@yahoo.com
}

Received : 24/10/2021

Acceptance : 26/11/2021

Available online: $31 / 12 / 2021$

\begin{abstract}
The Biskra region in Algeria is known for the production of very good quality Deglet Nour dates. This quality is the result of the interaction of several ecological and agronomic factors. Our work aims to study the impact of hydro-edaphic parameters on the quality of Deglet Noor dates, produced in the region of Biskra. The study is carried out in three stations: Tolga, Sidi Okba and Ouled Djelel. Three farms are chosen in each station. The methodological approach is based on Soil, water, biometric and biochemical analyzes on sampled dates. The results shows that the water irrigation have a high salinity in Sidi Okba station. The statistical analyzes (ACP) shows that, the high salinity of irrigation water is the main cause of soil salinization. This salinization reduces the biometric characteristics of dates (length, width and weight), and increases their total sugar content.
\end{abstract}

Keywords. Characteristics, Hydro-edaphic, Deglet Noor, Quality, Biskra.

\section{INTRODUCTION}

The Ziban region is one of the most important phoenicultural regions in Algeria, not only by production of dates; but also on the quality scale of the famous Deglet Nour date [1].The Deglet Nour date, export variety par excellence, represents $53.56 \%$ of the national production in dates. The Bikra region provides $49.38 \%$ of the national production in Deglet Nour [2]. According to $[3,4]$, the quality of dates is influenced by the type of cultivar and by environmental conditions. Our work aims to characterize the effect of some hydro-edaphic properties on the quality of Deglet Nour dates, produced in some palm groves in the Biskra region.

\section{MATERIAL AND METHODS}

\section{- $\quad$ Zone of Study}

The study was carried out at three stations in the Biskra region, known for significant production of Deglet Nour dates: Tolga, Sidi Okba and Ouled Djellal (Figure 1).

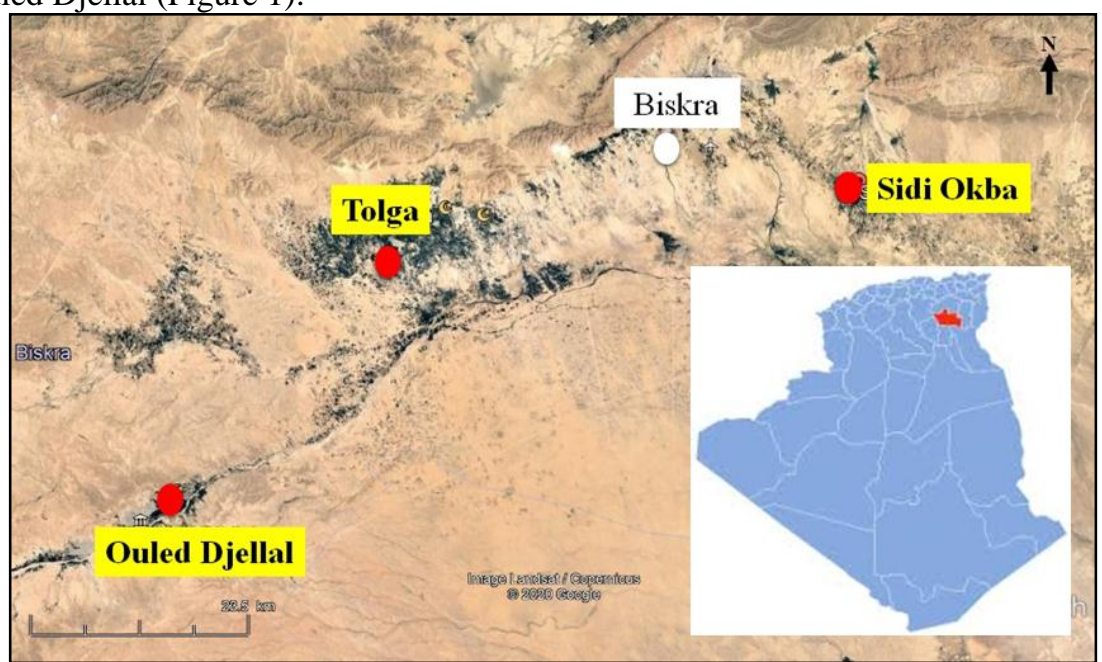

FIGURE 1. Presentation of sites of study [5]. 
- $\quad$ Methodological Approach

The objective of our work is to study of the influence of some hydro-edaphic characteristics on the characteristics of Deglet Nour dates in the Biskra region. In each station we have selected three (03) farms and the dates are taken from five (05) date palm trees at full production age. Water and soil samples are taken in front of each selected plant at a distance of $100 \mathrm{~cm}$. The analyses carried out are as follows: the length and the diameters of the dates using a calliper and their weight by a precision balance [6]. The water composition of dates by desiccation of the dates in the oven for 24 hours, their total sugars content by the method of Bertrand, reducing sugars by Fehling's method and in sucrose [7].

\section{RESULTS AND DISCUSSION}

\section{- $\quad$ Length and Diameter of Dates}

The length of the dates studied varies between $40.9 \mathrm{~mm}$ and $42.8 \mathrm{~mm}$. The width varies between $19.2 \mathrm{~mm}$ and $20.2 \mathrm{~mm}$ (Figure 2).

According to [8], a Deglet Nour date has, on average, a length of $60 \mathrm{~mm}$ and a diameter of $18 \mathrm{~mm}$. We note that the results found are lower than these values.

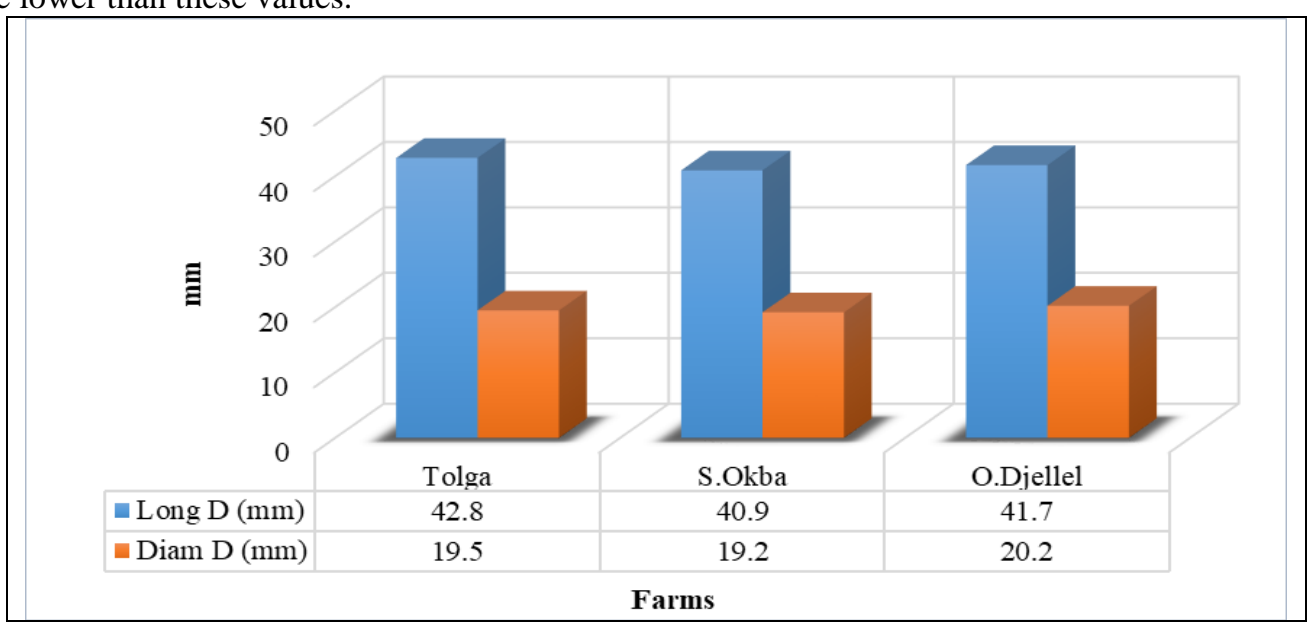

FIGURE 2. Length and width of dates.

- Weight of Dates

From the Figure 3, we found that the weight of the dates studied varies between $11.2 \mathrm{~g}$ and $11.8 \mathrm{~g}$. According to [9], a Deglet Nour date of good market quality has an average weight of $10 \mathrm{~g}$. we find that the dates studied meet this standard.

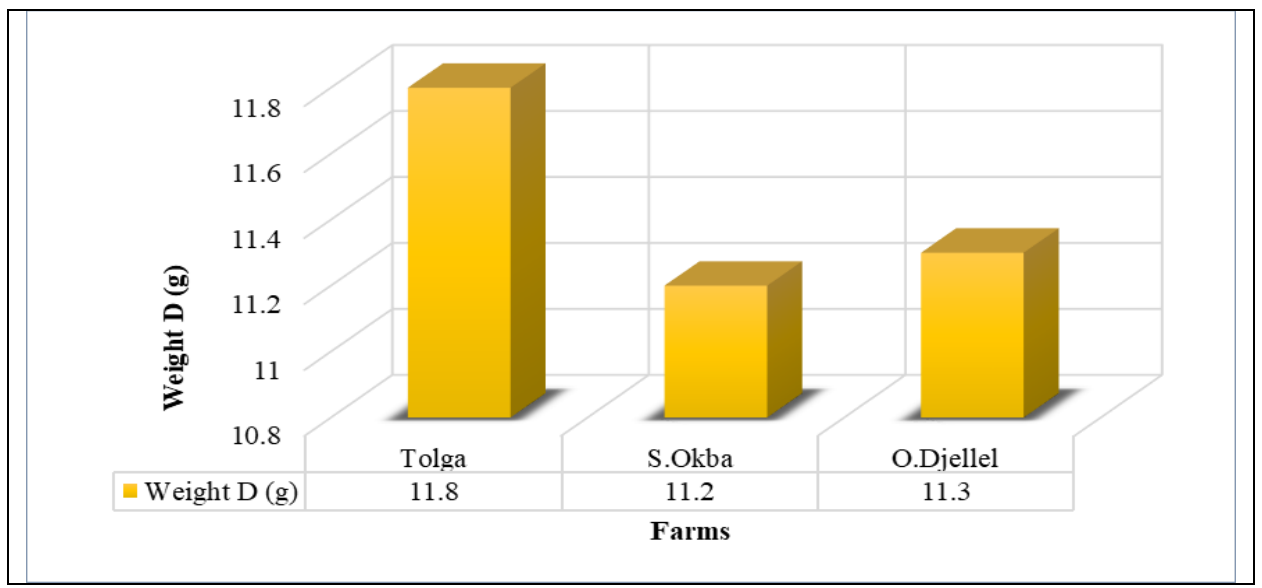

FIGURE 3. The weight of dates.

- Water Content

The water content of the dates studied varies between $22.57 \%$ and $26.8 \%$ (Figure 4). Our results are close to that given by [8], which is $25.52 \%$. 


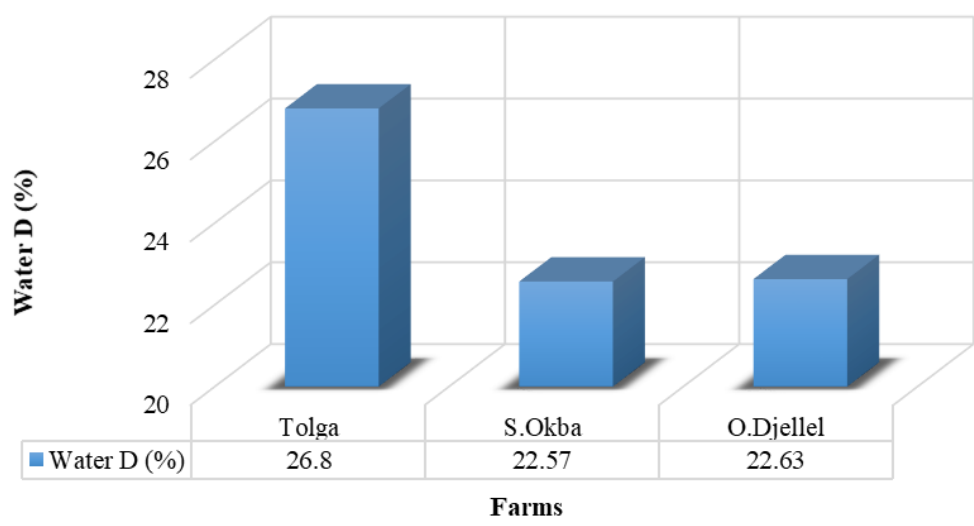

FIGURE 4. The water content of dates

- $\quad$ Total and Reducing Sugars

From Figure 5, we found that the total sugars vary between $46.79 \%$ and $53.37 \%$. The reducing sugars vary between $20.69 \%$ and $22.95 \%$. According to [8], the average total sugar content of Deglet Nour dates is $71.37 \%$, and the reducing sugars is $22.81 \%$. We found that our results are lower than the value of total sugars.

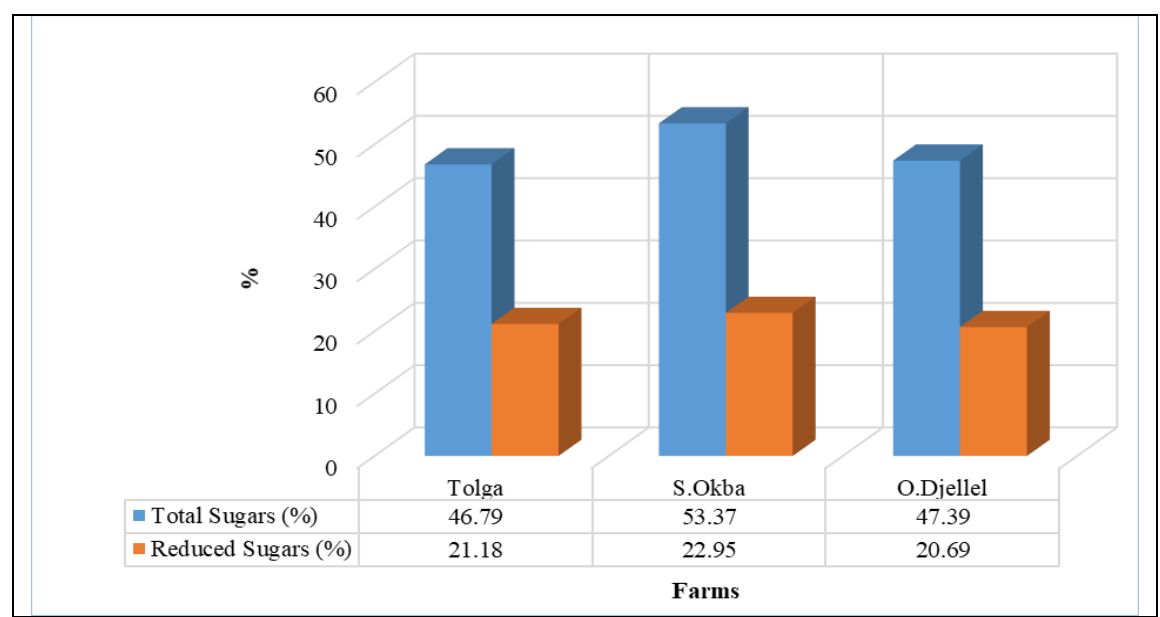

FIGURE 5. Total and reducing sugars .

- Water Salinity

La salinité des eaux exploitées pour l'irrigation varie entre $3.62 \mathrm{mS} / \mathrm{cm}$ et $6.14 \mathrm{mS} / \mathrm{cm}$. Ces eaux sont classées de fortement salines à excessivement salines (figure 6).

The salinity of water used for irrigation varies between $3.62 \mathrm{mS} / \mathrm{cm}$ and $6.14 \mathrm{mS} / \mathrm{cm}$. These waters are classified from highly saline to excessively saline, according to [10] (Figure 6).

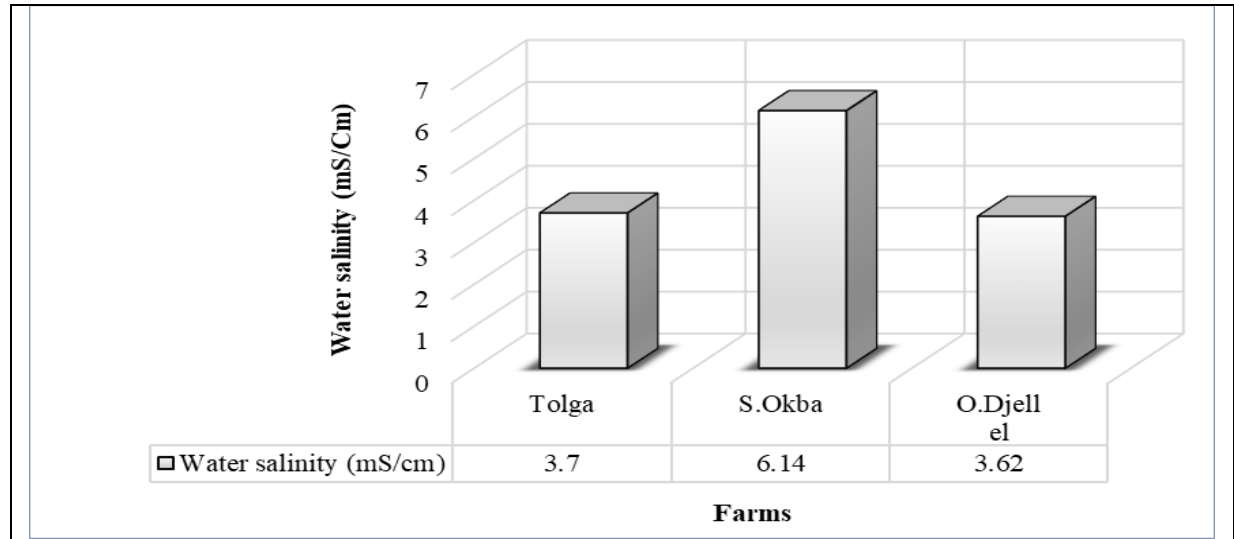

FIGURE 6. Salinity of water irrigation. 
- $\quad$ Soil Salinity

According to the scale of [11], we can classify the soil as slightly salty to salty in the O.Djellal station and very salty in Tolga and S. Okba (Figure 7).

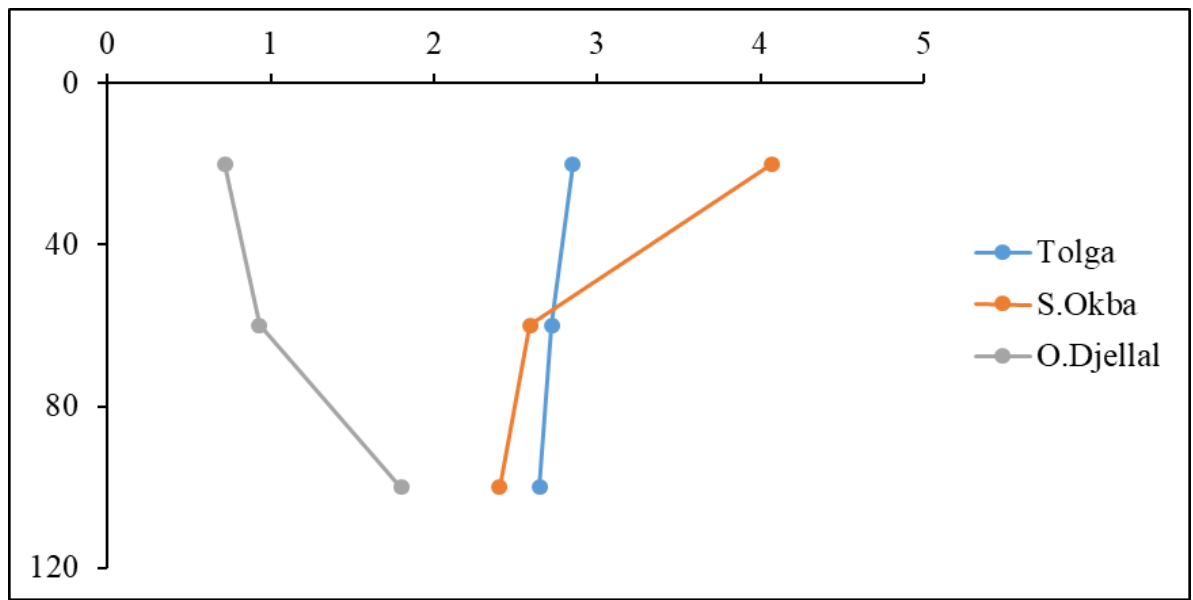

FIGURE 7. Salinity of soil.

- $\quad$ Analysis of the Relationship Between the Parameters Studied (Principal Component Analysis)

The Figure 8 represents the correlation between the characteristics chosen on the factorial plane F1/F2, which has the highest inertia $(75.85 \%)$. On the F1 plane, we find a strong positive correlation between the water salinity and the total sugar content and a strong negative correlation between the water salinity and : the length, diameter, weight and water content of dates.

For axis F2, there is a strong negative correlation between the salinity of the soil and the diameter of the dates.

These results are also confirmed by the studies of [12,13], on Deglet Nour dates in the Ouargla region.

According to [14], the biological energy of plants, used in the production of biomass will be consumed to extract water from the saline solution of the soil which has a high osmotic pressure. This results in the production of poor quality dates.

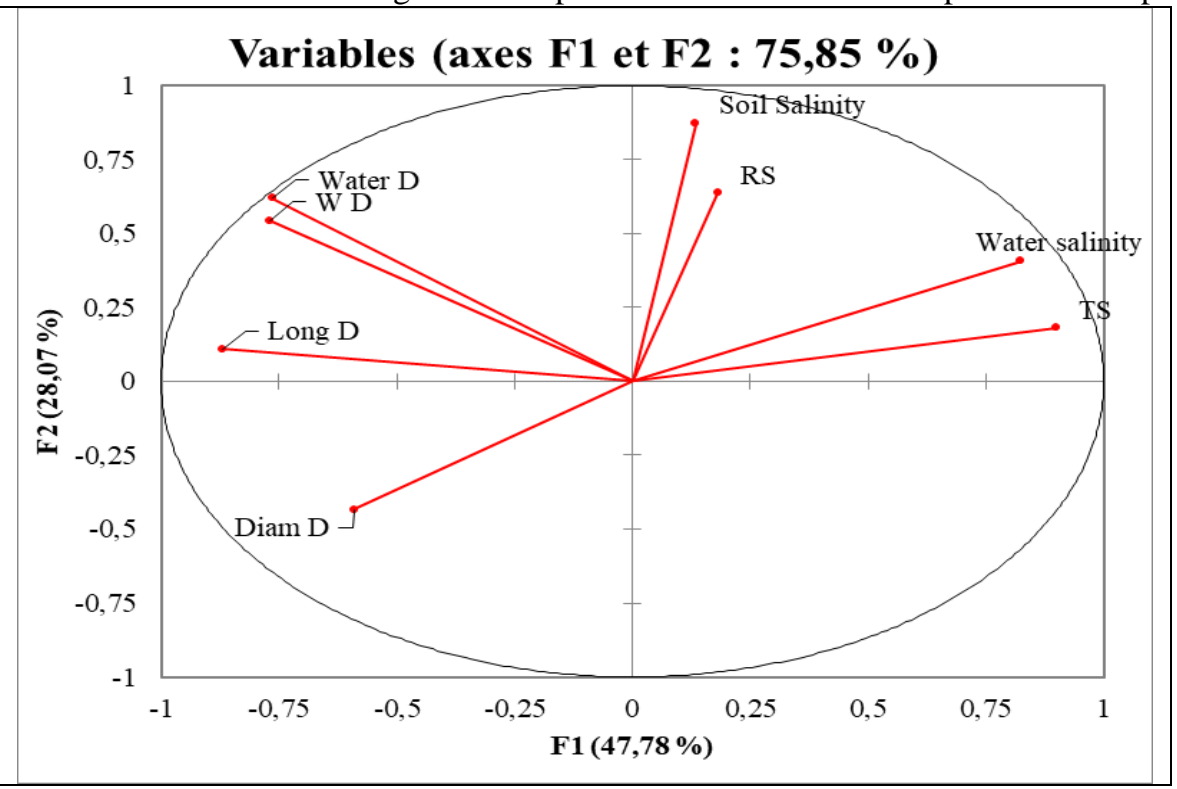

FIGURE 8. Principal Component Analysis of studied parameter.

\section{CONCLUSION}

The results of this study show that the Deglet Nour dates of Biskra have the characteristics that give them a good marketability. However, the high salinity of water and soil can affect this quality in the long term. 


\section{REFERENCES}

[1] S. Fadlaoui (2017). Applicalion de la technique de modélisation de l'architecture du palmier dattier (Phoenix dactylifera L.) pour la caractérisation des cultivars. Mémoire de Magister. Université de Biskra, Algérie.124 p.

[2] Ministère de l'Agriculture et du Développement Rural (MADR) (2020). Statistiques agricoles en Algérie : Série B. Rapport Ministère de l'Agriculture et du Développement Rural (données électroniques).

[3] B. Zougari El Wedi, Sanaa M, Labidi S, Lounes H et Sahraoui A (2012). Evaluation de l'impact de la mycorhisation arbusculaire sur la nutrition minérale des plantules de palmier dattier. Etude et gestion des sols. 19, 3, 193-202.

[4] A. Amoro, Rivera D, Larrosa E and Obon C (2014). Physico-chemical and functional characteristics of date fruits from different Phoenix species (Arecaceae). Fruits, 69, 315-323.

[5] Google Earth (2020). Images satellites de la région de Biskra.

[6] Institut International des Ressources Phytogénétiques (IPGRI), Descripteur du palmier dattier (International Plant Genetic Ressources Institute, French, 2005).

[7] C. Audigie, Figarlla J et Zonszain F, Manipulation d'analyse biochimique (Doin, Paris, 1984).

[8] M. Belguedj, Caractérisation des cultivars de dattier dans les palmeraies du sud-est Algérien (Institut National de la Recherche Agronomique, Alger, 2002).

[9] P. Munier, Le palmier dattier (Maisonneuve et Larousse, Paris, 1973).

[10] J.H. Durand, Utilisation des eaux salines pour l'irrigation (Institut National de la Recherche Agronomique, France, 1973).

[11] G.Aubert, Méthodes d'analyses des sols (Centre National de Documentation Pédagogique, Marseille, 1978).

[12] M. Haddou (2016). Diagnostic sur l'effet des conditions agro-écologiques sur la qualité des dattes Deglet Nour dans la région de Ouargla. Mémoire de Magister. Université de Ouargla, Algérie. 117 p.

[13] S. Ghezoula (2008). Contribution à l'étude de l'impact de l'environnement hydro-édaphique sur le stress salin et la qualité des sucres de dattes de deux variétés (Deglet Nour et Ghars) dans le pédopaysage de la cuvette de Ouargla. Mémoire d'ingénieur. Université de Ouargla. 69 p.

[14] J.D. Rhoades (1985). Salt problems from incresed irrigation effeciency. Journal of irrigation and drainage engineering, 111, 3, 218-229. 